\title{
Assessment of Oil and Gas Resources in the Upper Jurassic Haynesville and Bossier Formations, U.S. Gulf Coast, 2016
}

Open-File Report 2018-1135 



\section{Assessment of Oil and Gas Resources in the Upper Jurassic Haynesville and Bossier Formations, U.S. Gulf Coast, 2016}

By Stanley T. Paxton

Open-File Report 2018-1135 


\section{U.S. Department of the Interior \\ RYAN K. ZINKE, Secretary}

\section{U.S. Geological Survey James F. Reilly II, Director}

\section{U.S. Geological Survey, Reston, Virginia: 2018}

For more information on the USGS - the Federal source for science about the Earth, its natural and living resources, natural hazards, and the environment-visit https://www.usgs.gov or call 1-888-ASK-USGS.

For an overview of USGS information products, including maps, imagery, and publications, visit https://store.usgs.gov.

Any use of trade, firm, or product names is for descriptive purposes only and does not imply endorsement by the U.S. Government.

Although this information product, for the most part, is in the public domain, it also may contain copyrighted materials as noted in the text. Permission to reproduce copyrighted items must be secured from the copyright owner.

Suggested citation:

Paxton, S.T., 2018, Assessment of oil and gas resources in the Upper Jurassic Haynesville and Bossier Formations, U.S. Gulf Coast, 2016: U.S. Geological Survey Open-File Report 2018-1135, 13 p., https://doi.org/10.3133/ofr20181135.

ISSN 2331-1258 (online) 


\section{Assessment of Oill and Gas}

Resources in 1 ip Upper
Jurassic Hayns 5 ille and Bossier Fommations, U.S. Gulf Colst, 2016

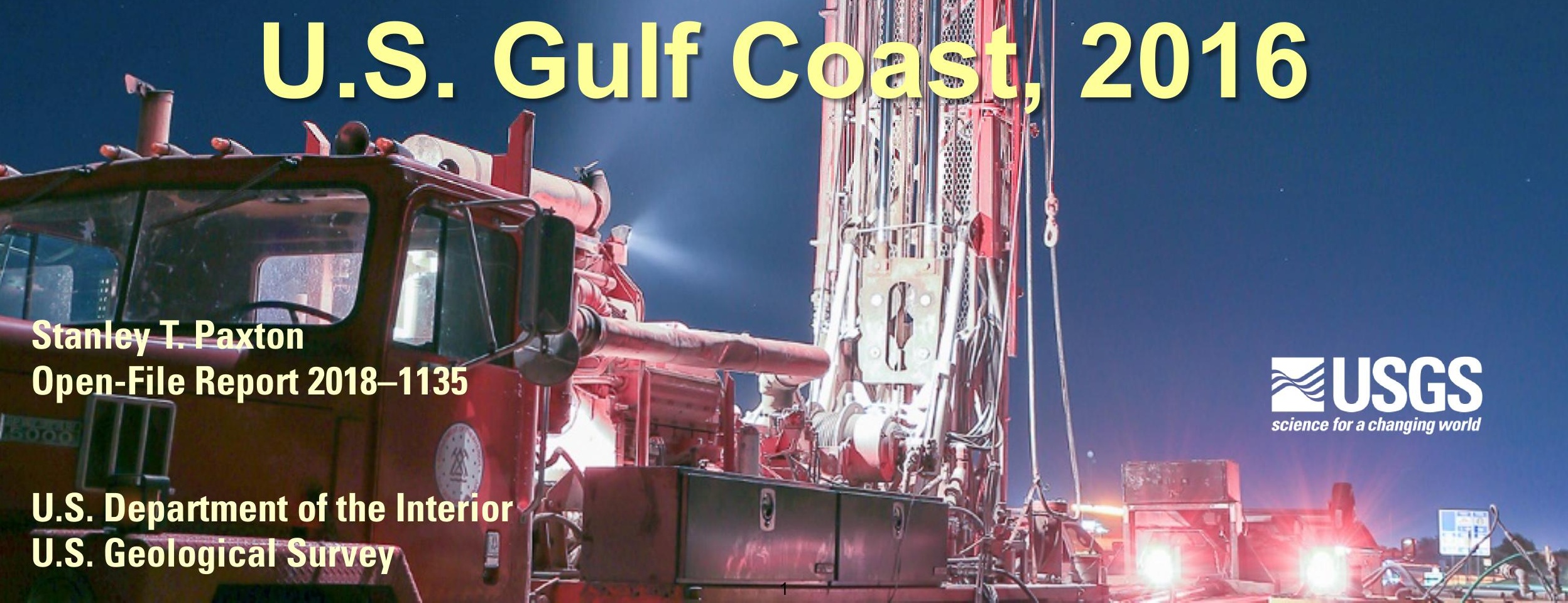


Assessment of the Haynesville

\section{and Bossier Formations}

- Haynesville Formation conventional oil and gas production began in the late 1930s; Bossier Formation production began in the early 1970 s

- Production of continuous gas resources from both formations began in 2006-7

- Last assessed by USGS in 2010

- Most current activity is focused on natural gas production from Haynesville and Bossier shales using horizontal wells and hydraulic fracturing 


\section{Haynesville and Bossier Production}

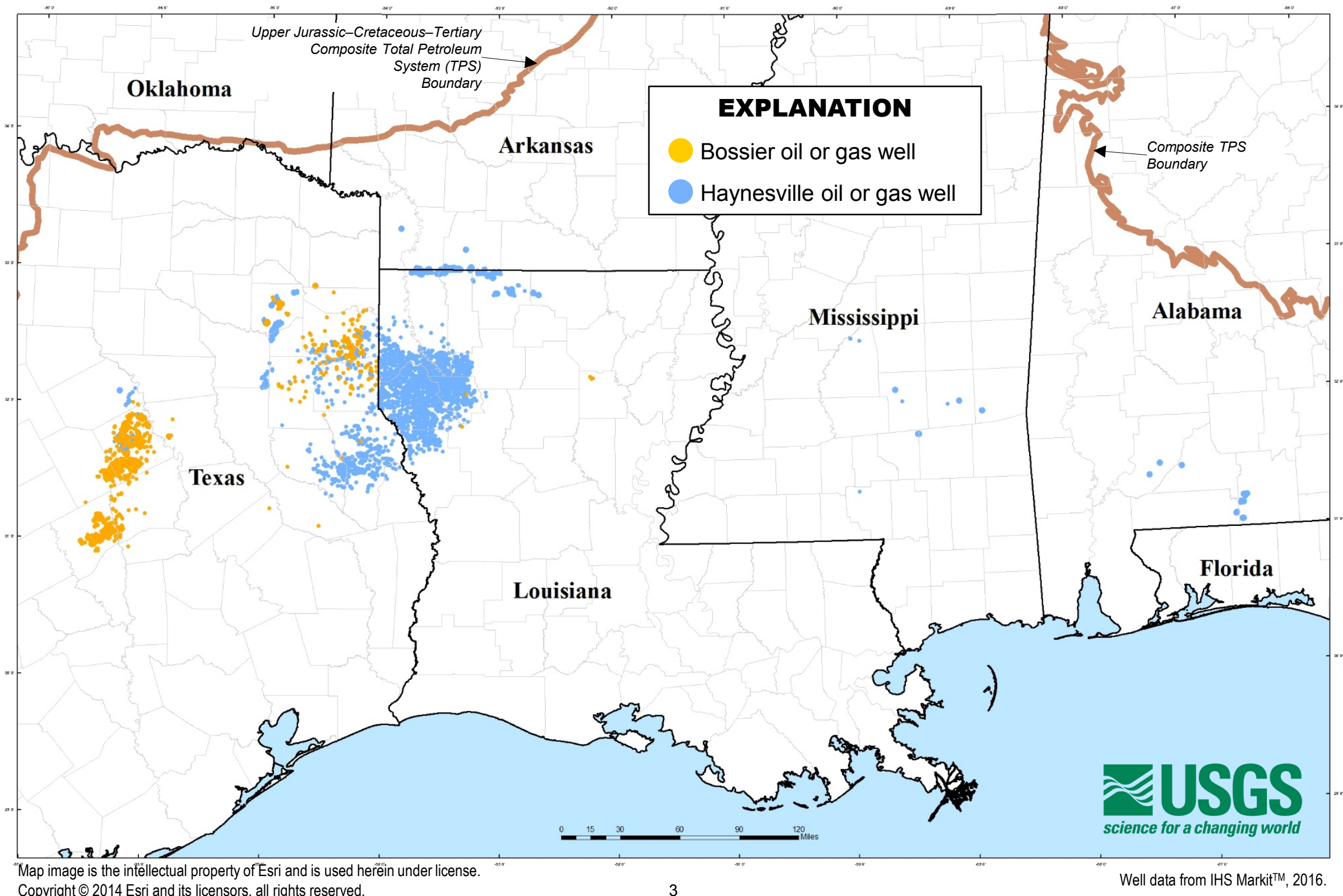




\section{Haynesville and Bossier Natural Gas by the Numbers}

- 27.3 trillion cubic feet of natural gas (TCFG) consumed by the United States in 20151

- Texas and Louisiana are major producers of United States natural gas

- Cumulative gas production as of August $2016^{2}$

- Haynesville Formation: 13.2 TCFG

- Bossier Formation: 2.9 TCFG 


\section{Conventional versus Continuous Resources}

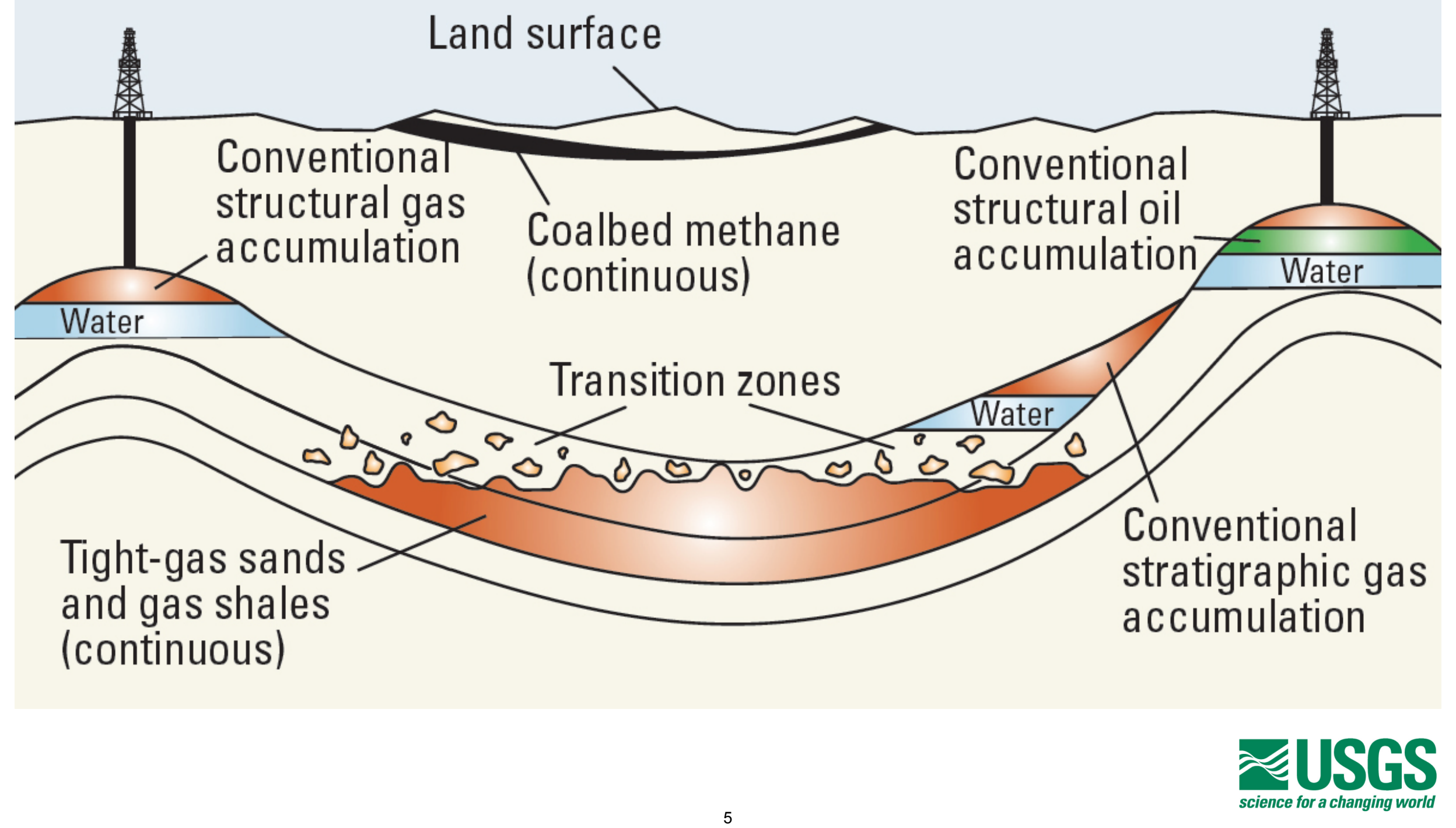


USGS Assessment Methodology for Continuous-Type Accumulations

- Based on geology and geologic models

- Identify and outline Total Petroleum System(s) and Assessment Units

- Emphasis on undiscovered, technically recoverable resources

- Not economically recoverable resource estimates

- Not in-place resource estimates

- Not reserves 


\section{Haynesville Formation Mean Assessment Results Per Conventional AU}

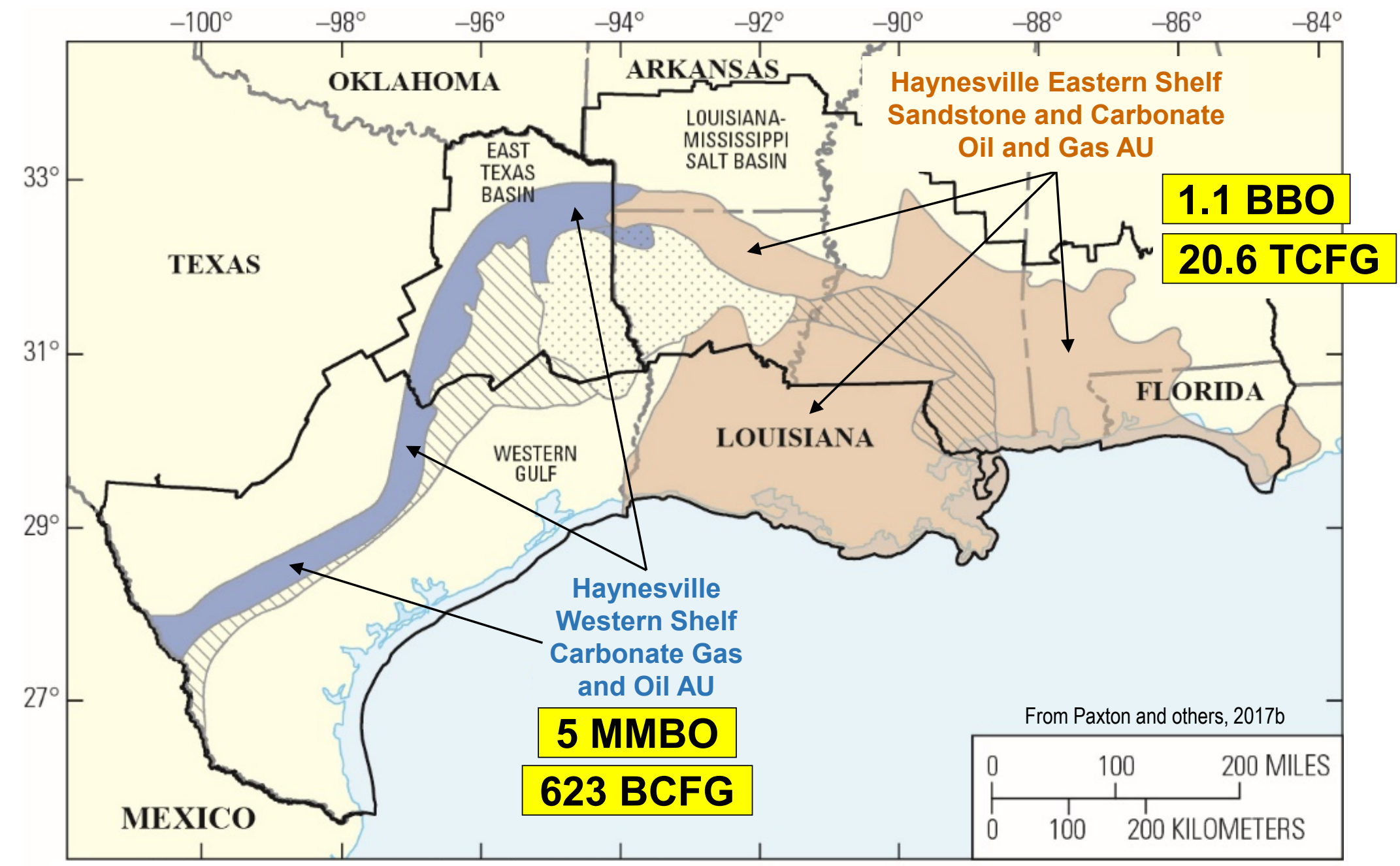




\section{Haynesville Formation Mean}

\section{Assessment Results Per Continuous AU}

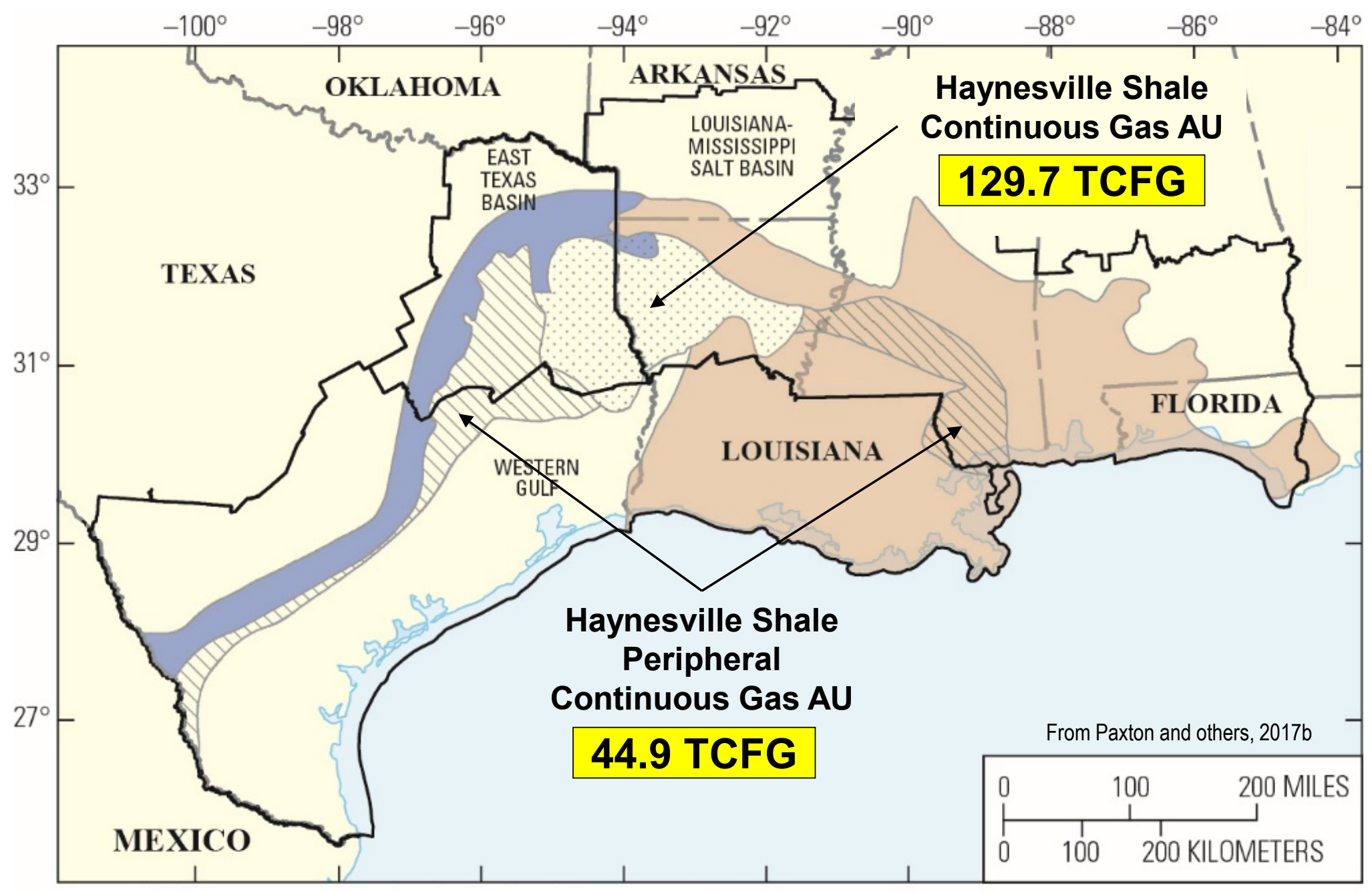

Base Map Source: U.S. Department of the Interior 


\section{Bossier Formation Mean Assessment Results Per Conventional AU}

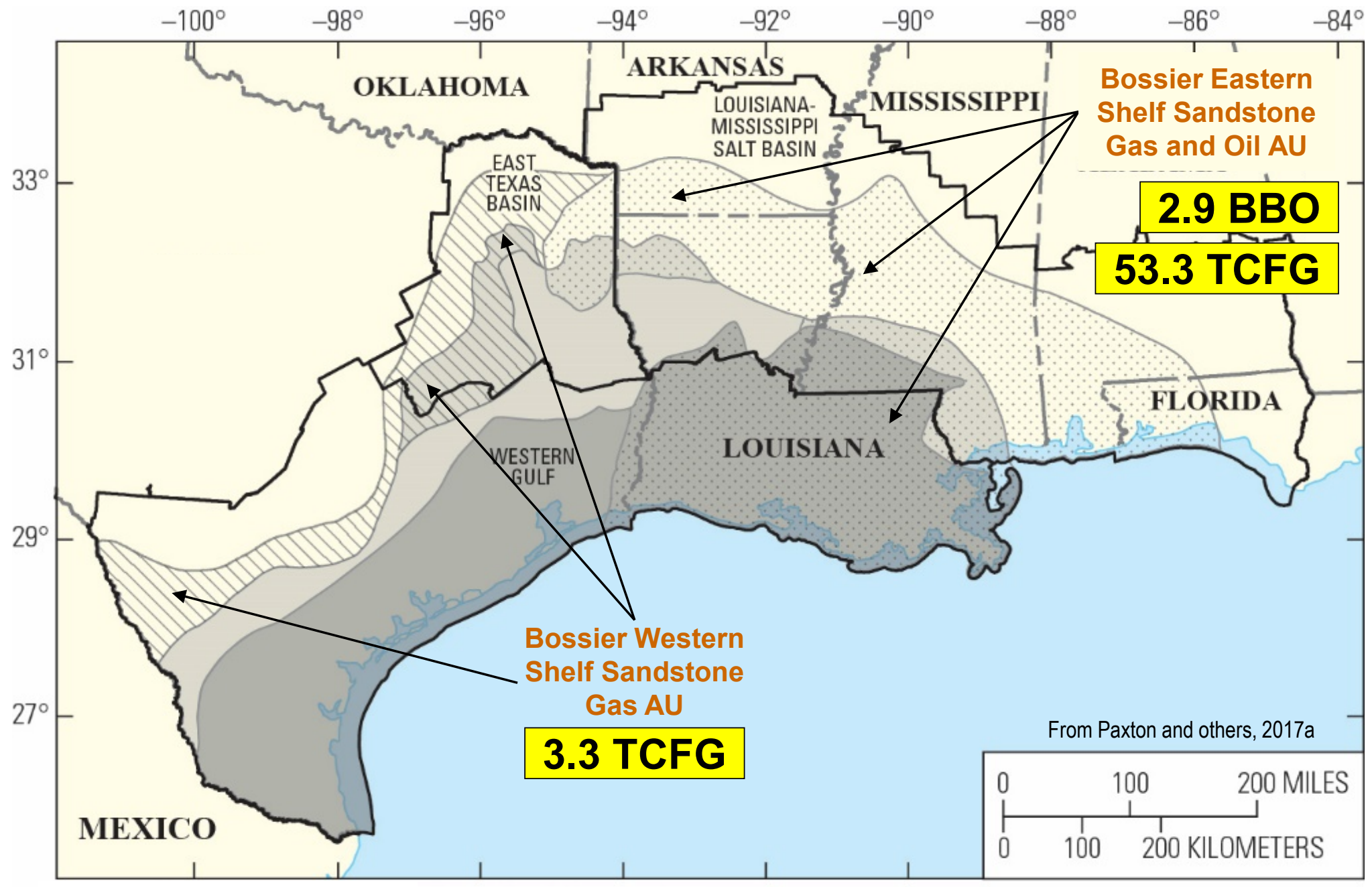

Base Map Source: U.S. Department of the Interior

National Park Service (December, 2009)

[AU, Assessment Unit; BBO, billion barrels of oil;

TCFG, trillion cubic feet of gas] 


\section{Bossier Formation Mean Assessment}

\section{Results Per Continuous AU}

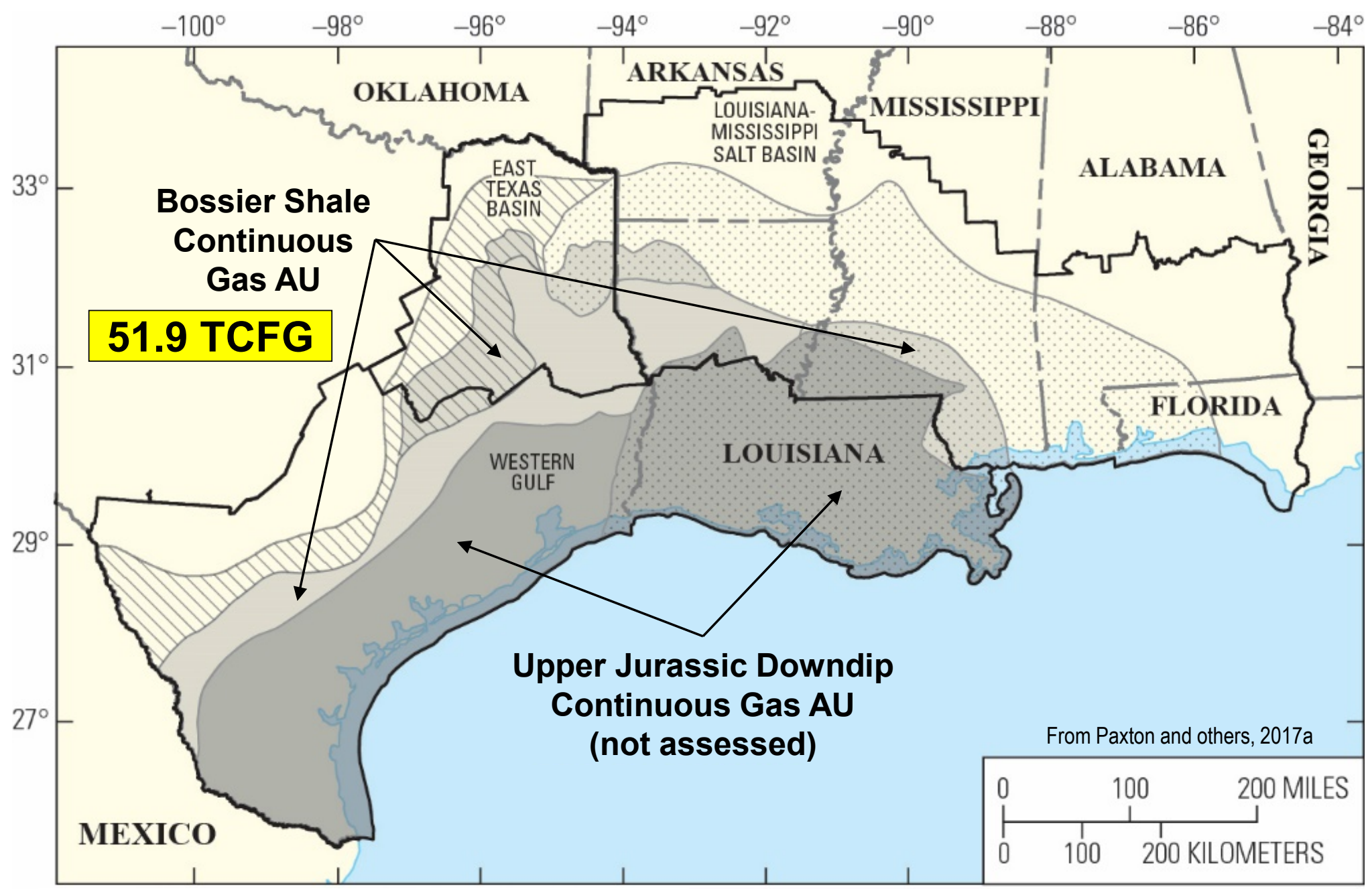

Base Map Source: U.S. Department of the Interior 


\section{Haynesville and Bossier Formations}

Assessment Summary (Combined)

Undiscovered, technically recoverable resources

Mean resources ( 7 assessment units)

- Oil: 4.0 billion barrels of oil

- Gas: 304.4 trillion cubic feet of gas (TCFG)

- Natural gas liquids: 1.0 billion barrels of natural gas liquids

\subsection{TCFG (F95-F5 range from 133.4 TCFG to 564.4 TCFG)}

${ }^{*} \mathrm{~F} 95$ = 95-percent probability that the gas volume (in the two formations combined) will contain at least 133.4 TCFG.

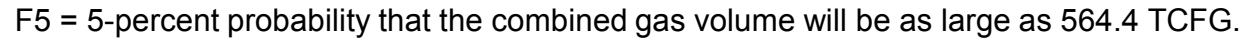




\section{Haynesville and Bossier Formations Largest Continuous Gas Resource Assessed by the USGS}

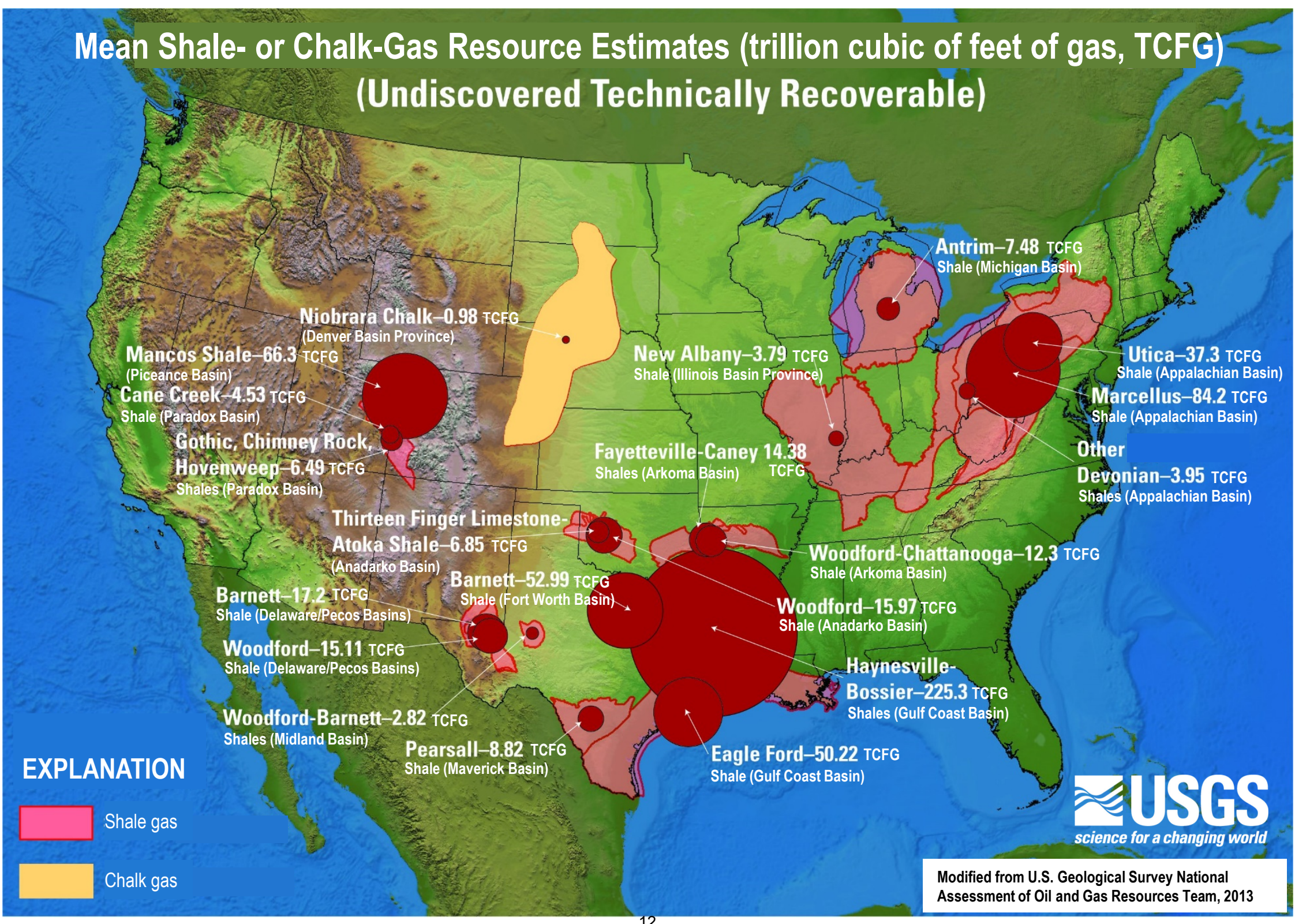




\section{References Cited}

- IHS Markit ${ }^{\top M}$, 2016, U.S. Well History and Production Database: Englewood Colo., IHS Markit, accessed August 2016 at http://www.ihsenergy.com. [Also available from IHS Markit, 15 Inverness Way East, Englewood, Colo., 80112.]

- Paxton, S.T., Pitman, J.K., Kinney, S.A., Gianoutsos, N.J., Pearson, O.N., Whidden, K.J., Dubiel, R.F., Schenk, C.J., Burke, L.A., Klett, T.R., Leathers-Miller, H.M., Mercier, T.J., Haines, S.S., Varela, B.A., Le, P.A., Finn, T.M., Gaswirth, S.B., Hawkins, S.J., Marra, K.R., and Tennyson, M.E., 2017a, Assessment of undiscovered oil and gas resources in the Bossier Formation, U.S. Gulf Coast, 2016: U.S. Geological Survey Fact Sheet 2017-3015, 2 p. [Also available at https://doi.org/10.3133/fs20173015.]

- Paxton, S.T., Pitman, J.K., Kinney, S.A., Gianoutsos, N.J., Pearson, O.N., Whidden, K.J., Dubiel, R.F., Schenk, C.J., Burke, L.A., Klett, T.R., Leathers-Miller, H.M., Mercier, T.J., Haines, S.S., Varela, B.A., Le, P.A., Finn, T.M., Gaswirth, S.B., Hawkins, S.J., Marra, K.R., and Tennyson, M.E., 2017b, Assessment of undiscovered oil and gas resources in the Haynesville Formation, U.S. Gulf Coast, 2016: U.S. Geological Survey Fact Sheet 2017-3016, 2 p. [Also available at https://doi.org/10.3133/fs20173016.]

- U.S. Energy Information Administration, 2016, Frequently asked questions, accessed April 2017 at http://www.eia.gov/tools/faqs/.

- U.S. Geological Survey National Assessment of Oil and Gas Resources Team, and Biewick, L.R.H., comp., 2013, Map of assessed shale gas in the United States, 2012: U.S. Geological Survey Digital Data Series 69-Z, 16 p., 1 pl., GIS data package, accessed April 2017 at http://pubs.usgs.gov/dds/dds-069/dds-069-z/. 
